\title{
Sustainable development of single-industry towns in Russia
}

\author{
Alexander Volkov ${ }^{1,2, *}$, Elena Pavlova ${ }^{2}$, Maria Valdaitceva $^{2}$, and Valery Abramov ${ }^{3}$ \\ ${ }^{1}$ Institute of Economics of the Ural Branch of RAS, 620014 Ekaterinburg, Russia; \\ ${ }^{2}$ ITMO University, 197101 St. Petersburg, Russia \\ ${ }^{3}$ Russian State Hydrometeorological University, 197107 St. Petersburg, Russia
}

\begin{abstract}
The modern practice of defining administrative-industrial territories has formed the concept of «single-industry towns». Currently, there are many definitions of this phenomenon; however, the common criterion for classifying a town as a single-industry town is that its socio-economic development depends on the activities of one city-forming enterprise or several enterprises in the technological structure that operate within a single production and technological process. Such dependence for settlements with narrow specialization has a negative impact during the crisis situation at the enterprise or its liquidation. The negative consequences include a sharp increase in unemployment (including hidden one), aggravation of social problems, acceleration of population outflow to more developed cities/regions of the region/country, sharply reduced revenues to the local budget, which leads to the impossibility of independent development of the settlement. The problems of single-industry towns in the periods of economic crises are pronounced. Results. This paper has defined the criteria of single-industry towns, approaches to the identification of single-industry towns. In addition, the models and factors contributing to the sustainable socio-economic development of single-industry towns and domestic experience in the modernization of single-industry town settlements are identified.
\end{abstract}

\section{Introduction}

The problem of single-industry towns emerged at the end of the 20th century, but it was not until 2008-2009 that serious efforts were made to address it. In those years, regional programmes to support and develop single-industry towns in order to diversify their economies began to be developed and implemented. In the framework of the regional policy the criteria for classifying a settlement as mono-profile were formed, a count of such mono-profile territories on the territory of the whole country was made, and in most cases a comprehensive investment development plan was elaborated. The main task of CIP is to solve the problem of unemployment, urban economy, as well as to increase the investment attractiveness of the single-industry territory. Despite the common features of single-industry towns, it is impossible to propose general measures to solve the problems of sustainable socio-economic development. Each settlement has a unique history of development and a unique socio-economic condition. One of the tasks of this article is to show this by analyzing the state of a number of towns. Comprehensive investment plans are developed taking into account the advantages and barriers to development of single-industry municipalities, the peculiarities of socioeconomic situation. The Ministry of Economic Development of the Russian Federation, the «Fund for the Development of Monotowns», the State Corporation «Vnesheconombank» currently «VEB.RF» have been assigned responsibility for solving the problems of single-industry towns. Despite the fact that the regional policy on singleindustry towns is relatively recent, there has been both negative and positive experience in modernising single-industry towns' economies. The theoretical and methodological basis of the research consists of the works of scientists in the field of economics, geography and geo-urbanism Turgel I.D., Manaeva I.V., Kashapov R.F., Krysin N.I., Nikolaeva I.V., Mestnikov N.A., Pavlova S.N., etc. The works of Lucas, Rex \& Tepperman, Lorne, Taylor, A., Carson, D.B., \& Carson, D.A., Boyle M. were considered as an example of foreign and domestic experience of modernization of monotown economies.

\section{Materials and methods}

A single-industry town is a complex multi-structural monofunctional system that concentrates significant amounts of material, financial and labour resources of the country. Today, it is in these cities that enterprises of the largest Russian corporations are located. Thanks to single-industry towns the country's export potential is formed, the geo-economic and geopolitical security of the country is ensured [1].

A single-industry settlement is a settlement that has emerged on the basis of a city-forming enterprise, which employs at least $20 \%$ of the working population, and the level of social development of the settlement depends on the

\footnotetext{
* Corresponding author: volkovra@yahoo.com
} 
financial condition of this enterprise [2]. The problem of single-industry towns is not unique to Russia, there are such municipalities in most countries, but for Russia these problems acquire the scale of the whole country. In times of crisis, various measures are used as a solution to the problems, the most common being point-by-point rehabilitation of troubled enterprises and development of an investment plan, the main purpose of which is to diversify the economy of the locality. Town-forming enterprises have long provided the population of a monotown not only with jobs, but also with housing and the entire social infrastructure - kindergartens, hospitals, schools, water, electricity, public transport. During the Soviet period, such cities attracted the workforce not only with high wages, but also with social benefits that were not available in other cities: a level of healthcare, high quality housing, the opportunity to buy a car. Single-industry towns carried the brand of increased comfort of living. With the transition to a market economy, the competitiveness of many city-forming enterprises declined sharply, which led to the emergence of crisis cities throughout Russia. Depressed and crisis municipalities with a high degree of risk and socio-economic problems have emerged $[3,4]$. The factors behind the emergence of single-industry towns are presented in Table 1.

Table 1. Factors for the emergence of single-industry towns.

\begin{tabular}{|l|l|}
\hline \multicolumn{1}{|c|}{ Factor } & \multicolumn{1}{|c|}{ Definition } \\
\hline 1. Macro-factors & $\begin{array}{l}\text { civilised challenges; changing types of socio-economic } \\
\text { system; changing types and sources of economic growth; }\end{array}$ \\
\hline 2. Meso-factors & $\begin{array}{l}\text { the features of state financial and economic and industrial } \\
\text { policy; the specific features of state regional policy and local } \\
\text { government relations policy; }\end{array}$ \\
\hline 3. Micro-factors & $\begin{array}{l}\text { narrow industrial specialisation; settlement patterns; economic } \\
\text { and geographical position, transport and natural geography. }\end{array}$ \\
\hline
\end{tabular}

In scientific literature, it is not uncommon to find the terms - monoprofile, monofunctional, monostructural, monospecialised, mono-industrial city - as a synonym. The most common example given is a monoprofile city. It can include any municipality, which is characterized by monospecialized economic development. But it should be noted that not every single-industry formation is a monocity. The concepts of «monostructural» and «monofunctional» are narrower and are applicable in particular cases - when considering the functions or structure of a settlement. The main typological characteristic of a monocity is that it belongs to an urban settlement. The literature also suggests the following features of a single-industry town:

- The presence of one or more single-type enterprises belonging to one industry or serving one narrow segment of the industry market, with other enterprises serving only the internal market of the town;

- High dependence of the settlement's budget on the activity of the city-forming enterprise;

- The existence of technologically related enterprises serving one and the same end market, except for those enterprises which serve the internal needs of the town;

- The majority of the population works at the backbone enterprise.

Developing the law of the subject of the Russian Federation «On the development of single-industry territories in (name of the subject of the Russian Federation)», the Ministry of Regional Development of the Russian Federation has developed two official criteria for attributing settlements to single-industry towns. It should be noted that in order for one of the criteria to be recognised as sufficient:

- The presence in the settlement of an enterprise (or several enterprises carrying out activities in the framework of a single production and technological process) that employs more than $25 \%$ of the economically active population; - The output of the enterprise or group of enterprises should amount to at least $50 \%$ of the industrial output of the locality;

- The share of tax revenues in the budget of the municipality from city-forming enterprises should be at least $30 \%$.

Based on these three criteria, on 13 May 2016, the Russian government signed amendments to the list of singleindustry municipalities of the Russian Federation (single-industry towns). This list included 319 names (29.1\% of the total number of Russian cities) [4]. Their population is more than $25 \%$ of the total urban population of the country (about 16 million people). The contribution of single-industry towns to the country's GDP ranges from 20-40\%. In physical terms town-forming enterprises provide $53 \%$ of coal mining, $64 \%$ of oil mining, $83 \%$ of gas mining, over $50 \%$ of ferrous metallurgy production, including $66 \%$ of steel and coke production, $65 \%$ of pig iron production, a considerable part of non-ferrous metallurgy production, including $90 \%$ of nickel and $100 \%$ of alumina, $84 \%$ of potash fertilizer production, $71 \%$ of automobile production, etc. [5].

Table 2 shows how the criteria for categorizing cities as single-industry towns have changed over time. As can be seen from the table, the constant criterion is the labour market. It has retained its high value for 20 years. Other criteria have been applied periodically, being of additional nature. Mono-cities were not officially monitored in $2003-2009$ $[6,7]$. 
Table 2. Modification of the criteria for classification as a single-industry town.

\begin{tabular}{|l|c|c|c|c|c|}
\hline Criteria/year & $1994-1998$ & $1998-1999$ & $1999-2001$ & $2009-2014$ & $2014-$ present \\
\hline Labor market & $\begin{array}{c}30 \% \text { of those } \\
\text { employed in } \\
\text { the economy }\end{array}$ & $\begin{array}{c}50 \% \text { of the } \\
\text { population } \\
\text { including family } \\
\text { members }\end{array}$ & $\begin{array}{c}25 \% \text { of the } \\
\text { working } \\
\text { population }\end{array}$ & $\begin{array}{c}25 \% \text { of the } \\
\text { economically } \\
\text { active population }\end{array}$ & $\begin{array}{c}20 \% \text { of those } \\
\text { employed in the } \\
\text { economy }\end{array}$ \\
\hline Budget & - & - & - & $30 \%$ & - \\
\hline Industry & - & - & $50 \%$ & $50 \%$ & - \\
\hline $\begin{array}{l}\text { Specialisation of } \\
\text { the city-forming } \\
\text { enterprise }\end{array}$ & \multicolumn{7}{|l|}{ industry } & $\begin{array}{c}\text { industry, } \\
\text { transport, military } \\
\text { units }\end{array}$ & $\begin{array}{c}\text { industry (except oil } \\
\text { and gas industry) }\end{array}$ \\
\hline $\begin{array}{l}\text { Status and size } \\
\text { of the city }\end{array}$ & - & - & - & - & $\begin{array}{c}\text { city status from } \\
3,000 \text { people }\end{array}$ \\
\hline
\end{tabular}

In 1994, one of the criteria for city-forming enterprises was to maintain the municipal infrastructure on their balance sheet. In 1998, most of the responsibility for maintaining social facilities was transferred to the municipality. Also, a criterion was introduced that took into account the family members of the enterprise's employees. In 2002, the list of single-industry settlements was expanded by replacing the term «enterprise» with «city-forming organization». Now they include not only factories, but also transport centres, military units, and institutions of the Federal Service for the Execution of Punishments.

In 1999 the The Ministry of Labour and Social Protection (Mintrud) formed the criteria for classification as singleindustry enterprises, which are used nowadays. As Russian scientists describe in their studies, these criteria primarily evaluated the dependence of the labor market on city-forming enterprises and its structure of industrial production [6, 14]. However, the second criterion often became the reason for wrong classification of towns in the list of singleindustry settlements. This is how the term «false» single-industry towns appeared. The problem is that for them industrial functions are not the only and determining factor for their classification as mono-cities. In this connection, the indicator of the share of industrial production of the city-forming enterprise in the total structure of industrial production of the urban settlement, in practice, is not determinative, as it does not reflect fully the dependence of the city on the city-forming enterprise. A more difficult to calculate, but more illustrative criterion for attribution to singleindustry towns is for tax deductions to the city budget from the city-forming enterprise. This criterion reflects the economic type of dependence. However, due to the complexity of calculations, it was abolished, probably also due to the interbudgetary transfers that solved the problems with the local budget deficit.

The managed contraction model is completely new to Russia. As the study revealed, Russia's single-industry towns have many similar problems, which means that it is more likely that model development models can be adapted for all Russian single-industry towns $[8,10]$.

\section{1 «Managed compression» model}

This model is a set of measures to optimize the territory of the settlement and provide employment or relocation of residents under conditions of suspension or closure of the city-forming enterprise. The alternative to the managed contraction model is the growing degradation of the settlement, the results of which would be popular discontent and unorganised protests [11]. The implementation of this model requires close interdepartmental cooperation, as well as the involvement of local and regional authorities. It is also necessary to coordinate the actions of the authorities and the owners of the city-forming enterprise.

This model is applicable to single-industry towns with a critically high level of dependence on the city-forming enterprise, which provides the main number of jobs in the real economy, as well as provides the municipal infrastructure. Such towns are characterised by low population numbers (less than 10,000) with natural decrease in population, high migration flows, low demographic potential, and low purchasing power. These municipalities are located on the periphery, far from any large cities/centres of economic growth, which obviously puts them in a difficult situation [12]. The social environment is a closed one. The population has a predominantly industrial mentality. The level of social and territorial mobility and entrepreneurial activity is extremely low [20].

The complication of the situation at the city-forming enterprise sharply leads to a prolonged economic depression, an increase in social tension, and the low level of own investments does not allow the creation of an "alternative economy» $[9,16]$. The main objectives of the implementation of the «managed compression» model are:

- Reducing the negative socio-economic consequences associated with the suspension or closure of a city-forming enterprise;

- Assistance in the resettlement of working-age families and provision of social guarantees to residents who remain in the municipality;

- Shrinking the city's residential space - optimisation of infrastructure and housing stock due to a declining population. 


\subsection{The Stable Single-industry town model}

This model is applicable to those municipalities that will remain single-industry towns in the foreseeable future, as there is insufficient potential for diversification.

City-forming enterprises of such cities maintain relatively stable production volumes in the medium term. A modernisation or winding-up programme will play a key role in the labour market, budget formation and the existence of such settlements in general. Unfortunately, such towns are not part of Russia's federal programme to support singleindustry towns. The main task of municipal authorities is to provide a high level of social services. Municipal authorities must uphold the interests of the city in district and regional administrations. Entrepreneurs should cooperate closely with the city administration in maintaining social programs. This model is applicable to $35 \%$ of the cities on the «crisis» list. According to preliminary calculations, about 1.5-2 billion roubles will be required to solve the problems of these cities [13].

\subsection{Industrial Diversification model}

There are three types of this model. The variant of the model is determined by analyzing the existing structure of the economy, the potential for the creation of new enterprises and the prospects of the city-forming enterprise.

- The model of industrial diversification of a single-industry town is applicable to settlements that have not yet embarked on the path of industrial diversification of the economy and still have the character of a single-industry economy.

A characteristic feature of the socio-economic development of such cities is the dependence on the city-forming enterprise in the periods of its economic strain. However, the cities in this group have investment potential or opportunities to attract investment.

Diversification of the economy in such cities should be ensured through the creation of new enterprises, sustainable development of the social sphere and improvement of the quality of life, as well as increasing urban infrastructure in order to attract qualified specialists. The local authority has to select and prepare the industrial site, while the regional administration is in charge of setting up the infrastructure, finding strategic investors as well as supporting the projects. - The model of sustainable development of diversification of the city with a closing city-forming enterprise is applicable to the cities that started on the path of industrial diversification and have lost the status of a single-industry municipality.

Cities in this category have an advantageous location within large urban agglomerations. This location helps to mitigate the situation associated with the closure of the city's major enterprise and also helps to attract investors. Often, these cities have more than one major enterprise that is loosely connected to each other, so the closure of one of them will have less impact on the socio-economic situation of the population.

- The model of sustainable development of diversification of the city with an operating city-forming enterprise is also applicable to the cities that implement the policy of industrial diversification and have lost the status of a singleindustry town $[15,18]$.

\section{Results and discussion}

The Russian experience of modernising single-industry towns. A special policy towards mono-profile areas began to be implemented during the Soviet Union in the 1960s. This policy was mainly implemented in the coal-mining settlements of the Moscow lignite and Ural basins. The workers in the coal mining areas were laid off, necessitated by the need to create new jobs for them, and the problem of further development of the coal mining settlements was brought up to date. Some of these settlements (with a low population) were closed down, and in the densely populated ones, new industrial plants for machinery, food and light industry were built. It was decided not to close the mines until a new generation of miners had been retrained. In connection with this, retraining courses were organised. Measures to create new types of industries and provide them with qualified employees generally solved the problem of single-industry municipalities. After the break-up of the union territories, a massive systemic crisis began to affect the whole country. During this period, the problems of the development of mono-profile territories of all industries and regions became particularly acute. Until 2003, mono-settlements were monitored by the Russian authorities, but there were no measures and large investment projects to diversify the economy of mono-settlements, and after 2003 monitoring ceased as well $[1,18]$.

After the 2008 crisis, a new programme for the development of single-industry towns was launched. One of the striking reasons for the return to solving this problem was the social explosion in Pikalyovo (is a town in Boksitogorsky District of Leningrad Oblast) in 2009. Since the end of last year, three enterprises in Pikalyovo stopped production: Pikalyovsky Cement (part of the Eurocement Group holding company), Bazelcement-Pikalyovo (part of Bazelcement) and Metachem (part of the Sevzaprom management company). The problem is that all three enterprises were designed as a single technological complex back in the Soviet times. However, their new owners have not been able to reach an agreement on cooperation for over a year now. Previously, the cement plant produced cement based on alumina, which was supplied by the Pikalyov Alumina Refinery, part of Bazelcement. The union of the Pikalyov Alumina Refinery was going to rally outside the Leningrad Oblast government building. Valery Serdyukov, the 
region's governor, demanded that the owners deal with the situation within two weeks, threatening that the Russian General Prosecutor's Office would get involved after that. The Ministry of Regional Development of Russia together with the state corporation Vnesheconombank analyzed the comprehensive investment plans for the development of single-industry settlements, some of them were financed from the federal budget. The development of single-industry towns and city-forming enterprises was also monitored. Each single-industry town was obliged to report quarterly on the socio-economic situation in the single-industry town, as well as on the functioning of the backbone enterprise.

The highest amounts of funding aimed at the diversification of single-industry territories were allocated in 2010 . In 2018 , money from the federal budget was allocated for investment projects in 26 single-industry towns, while 35 towns received subsidies for small business development and funds for housing reform.

Cities with high population densities and located in relatively developed regions received large funding. These included some cities in the Republic of Tatarstan, the Kemerovo and Sverdlovsk oblast, and the city of Tolyatti. The Kemerovo region stands out in particular. It has established 3 regional special economic zones and carried out many investment projects that have nothing to do with the Kuzbass industry. On a smaller scale, similar activities have been carried out in Tatarstan [17, 19].

The main focus of comprehensive investment plans is the creation of industrial parks, which have various specialisations. They are located in small towns with the aim of creating an industrial cluster. Zhigulevskaya Dolina stands out of all the industrial parks. Its territory produces high-tech products. On the basis of this park, a federal economic zone, Togliatti, was created. The industrial parks were characterised by low labour intensity. Despite the fact that 50 thousand people were laid off from the city-forming enterprise AvtoVAZ from 2009 to 2014, the Zhigulevskaya Dolina Technopark employed 250 people by the end of 2014, and the Special Economic Zone Tolyatti employed about 300 people [9].

The next solution to the problem of single-industry towns is state support for city-forming enterprises. Satka, Kamensk-Uralsk, Semiluk, Severodvinsk received financial support. Also, investments from the state budget were allocated for the development of the agro-industrial complex. The towns of Pikalyovo, Kamskie Polyany, Pavlovo and Naberezhnye Chelny received the largest investments. In order to diversify the economy of a single-industry town, financial support was provided to enterprises unrelated to the activities of the town's parent enterprise.

State financial support has also been provided for infrastructure projects. Approximately RUB 800 million has been allocated for the construction of road interchanges. The construction of roads is intended to promote agglomeration links. Investments have been directed to Nizhny Tagil's promising logistics centres. The Tashtagol ski resort «Sheregesh» is a successful example of implementation of a tourist investment project.

Successful investment projects include the production of syntactic sapphire in Naberezhnye Chelny and solar modules in Novocheboksarsk. Today, the Ministry of Economic Development of the Russian Federation monitors the social and economic development of single-industry towns and compiles a list of such towns. The Monocities Development Fund, formed in 2014, provides co-financing for the reconstruction and construction of infrastructure for new investment projects and training for management team leaders.

\section{Conclusion}

As the domestic practice shows, the main directions of successful modernization of the direction of sustainable development of single-industry towns are the use of all its advantages. It is also worth noting that improvements are observed in those municipalities where the main efforts of the authorities have been focused on the development of small and medium-sized businesses. The close relationship between the local authorities and the owners of the cityforming enterprise and business is also important. To sum up, we can conclude that the problem of sustainable development of mono-cities has existed for a long time and is not unique to the Russian Federation. There are many definitions and classifications of single-industry urban settlements, but the main criterion of this definition is that it is a municipality that was built around the city-forming enterprise and exists thanks to it. Also, the overwhelming part of the population works in the city-forming enterprise, which indicates low professional mobility. Basic Element Group has so far proposed three promising models for the economic modernisation of single-industry towns: controlled contraction, sustainable single-industry towns, and industrial diversification [20]. The main feature of successful modernisation can be seen as diversification of the economy by making use of the mono-city/region leadership's own advantages. All efforts have not been thrown into modernisation and support of the city-forming enterprise; the main directions have been the development of small and medium-sized businesses and increasing investment attractiveness by developing the urban environment and increasing social activity.

\section{References}

1. I.D. Turgel, Monofunctional cities of Russia: from survival to sustainability (2010)

2. A. Azarova, Aytalina, The Lancet Public Health, 2(5), 231 (2017)

3. T Men, P Brennan, P Boffetta, D Zaridze, Russian mortality trends for 1991-2001: analysis by cause and region BMJ, 327 (2003), 
4. CIP (2017), Comprehensive investment plan for modernizing the monotown of Kirovsk and adjacent territories in Murmansk Oblast, http://minec.gov-murman.ru/documents/kiro.pdf

5. Single-industry towns in Russia: how to survive the crisis? Analysis of socio-economic problems of singleindustry towns in the context of the global financial and economic crisis affecting the state of city-forming corporations. Moscow: Institute for Regional Policy Problems, http://www.regionalistica.ru/projects/detail.php?ELEMENT_ID=385 (accessed: 17.03.2021) (in Russian).

6. V.Y Lyubovny, G.Y Kuznetsova, N.I Vlasova, I.V Grivina, Ways to enhance socio-economic development of single-industry towns in Russia (Moscow, 2004)

7. V.G. Glushkova, Y.A. Simagin, Social and Demographic Problems of Russia, http://docplayer.ru/36277056Demografiya-pod-redakciey-professor-v-g-glushkovoy-i-docenta-yu-asimagina.html (accessed 15.03.2021) (in Russian).

8. Pikalyov Explosion. Expert online. http://expert.ru/2009/03/6/pikalevo/

9. Proceedings of the International Forum "Toliyatti. City of the Future", Expocenter Toliyatti, http://future-tgl.ru

10. Glasgow, European City of Culture: making sense of the role of local state in urban regeneration. (PhD Thesis. University of Edinburg, 1992)

11. Strategies for the Development of Old Industrial Cities: International Experience and Prospects in Russia (Publishing house of the Gaidar Institute, 2011)

12. M. Murphy, M. Bobak, A Nicholson, R Rose, M Marmot, Public Health, 96, 1293 (2006)

13. V. Trifonov, AIP Conference Proceedings, 1, 1800 (2017)

14. L.M. Grigor'ev, N. V. Zubarevich, D. S. Ivanov. Rossiiskie regiony: ekonomicheskii krizis i problemy modernizatsii ( TEIS, 2011).

15. D.Y Zemlyansky, S.V Lamanov, Vestnik Moskva, 4 (5), 69 (2014)

16. L. Rex, T. Lorne, Minetown, Milltown, Railtown: Life in Canadian Communities of Single Industry ( OUP Catalogue, Oxford University Press, 2008)

17. A. Taylor, D.B. Carson, D.A. Carson. Demographic Modelling of the Town of Nhulunbuy. (Darwin: Northern Institute, Charles Darwin University, 2014)

18. G.Yu. Kuznetsova. Geographical study of monoprofile settlements in Russia (Thesis, 2003)

19. V.K. Chumakov, Regional problems of economic development (BGU, 2008)

20. U. Yevhen, European Urban and Regional Studies 1.2, 161, (2020) 